\title{
Yerel Yönetimlerde Performans Ölçümü ve Göstergeler
}

\author{
Haydar KARAASLAN ${ }^{1}$
}

\section{Özet}

Kamu yönetimi alanında kaynakların etkin kullanımını sağlamak üzere stratejik planlama çalışmaları 2006 yılından itibaren uygulamaya konulmuştur. Beş yıllık hedeflerin yer aldığı stratejik plan, yıllık performans programı ile uygulamaya konulmakta, göstergeler üzerinden başarı faktörleri belirlenerek kurumun gelişimi izlenmektedir.

$\mathrm{Bu}$ sürecin başarılı bir şekilde ilerlemesinde "göstergeler" kritik bir öneme sahiptir. Hem uzun vadeli amaç ve hedefler; hem de yıllık hedeflerin başarısının merkezinde "göstergeler" yer almaktadır. Hedeflerin ve faaliyetlerin maliyet/bütçe boyutu da yine göstergelere bağlı olarak şekillenmektedir. Göstergelerin kalitesi, hedeflerin ve topyekûn stratejik planlamanın kalitesini büyük ölçüde ifade etmektedir. Göstergeler, hedef ya da faaliyet hakkında yeterli ve güvenilir veriler barındırmıyorsa üst yönetimin karar sürecine veri sağlaması beklenen performans programı yeterli sonuca ulaşamayacaktır. Dolayısıyla göstergeler, performans yönetiminin en hassas unsurlarından biridir.

Anahtar Sözcükler: Performans Programı, Performans göstergeleri, Yerel yönetimler, Ölçme değerlendirme

${ }^{1}$ Haydar Karaaslan, Ümraniye Belediyesi, Strateji Geliştirme Müdürü, e-mail: haydarkaraaslan@msn.com 


\title{
Performance Measurement and Indicators in Local Government
}

\begin{abstract}
Strategic planning has been implemented since 2006 to ensure the efficient use of resources in public administration includes local governments. The five-year strategic plan that includes goals, programs being implemented by annual performance, the indicators identified through the development of corporate success factors are monitored.

It is at the center of administrative activities that is "measure". The result of the success of both the long-term goals/objectives and the annual target as well as in the heart of the success "indicators" are included. The cost and size of the budget and operational goals are taking shape, depending on the performance indicators. Therefore, the quality of the indicator is largely represents the quality objectives and overall strategic planning. Therefore indicators, is one of the most critical elements of performance management.
\end{abstract}

Keywords: Performance Indicators, Performance Program, Assessment And Evaluation

\section{Giriş}

Kamu yönetimi alanında kaynakların etkin kullanımını sağlamak üzere 2006 yılından itibaren uygulamaya konulan stratejik planlama ve performans yönetimi çalışmaları yerel yönetimleri de kapsamaktadır. Bu kapsamda beş yıllık hedeflerin yer aldığı stratejik plan, yıllık performans programı ile uygulamaya konulmakta, göstergeler üzerinden başarı faktörleri belirlenerek kurumun gelişimi izlenmektedir. 2006 yılından beri neredeyse tüm yerel yönetim birimlerinde stratejik plan, buna bağlı olarak performans programı ve faaliyet raporları hazırlanmaktadır. Ancak yerel yönetimler tarafından yayınlanan planlar ve uygulamalara bakıldığında bir yönetim aracı olan planlamanın çoğunlukla şablonik ve yüzeysel ele alındığı, konuyu önemseyip planlama sürecini iyi yönetmek isteyen kurumların da yeterli başarıyı sağlayamadığı görülmektedir. $\mathrm{Bu}$ sürecin istenilen düzeyde sonuç vermemesi elbette birçok faktöre dayanmaktadır. Ancak en önemli sebeplerinden biri "gösterge" mantığının yerleşmemiş olması, gösterge kalitesi ve güvenilir verilerle hedeflerin objektif olarak ölçülememesidir. Performans yönetim sürecinde ölçülebilirlik, göstergelere bağlı olarak sağlanmaktadır. Göstergelerin sağlıklı sonuç vermesi ise hem faaliyetlerin iyi analiz edilmesine hem de veri kaynaklarının elverişli olmasına bağlıdır. Performans yönetim sürecinde belirleyici bir faktör olan göstergeler, hem uzun vadeli amaç ve hedefler hem de y1llık hedeflerin kurumsal gelişime ve politikalara yön verebilme becerisinin ne düzeyde 
gerçekleştiği konusunda veri sağlamaktadır. Hedeflerin ve faaliyetlerin maliyet/bütçe boyutu da yine göstergelere bağlı olarak şekillenmektedir. Diğer taraftan etkinlik ve verimlilik sorgulaması yapılabilmek için de göstergelere ihtiyaç vardır. Dolayısıyla tüm performans yönetim sistematiği üzerinde belirleyici bir etkisi olması bakımından bu çalışmada “göstergeler" üzerinde durulmaktadır.

Çalışmanın temel amacı stratejik planlama ve performans yönetimi konusunda yerel yönetimlerin daha başarılı sonuçlar elde etmesine katkı sağlamaktır. Bunun için performans yönetiminde başarı ya da başarısızlığı etkileyen en kritik unsurlardan biri olan göstergeler incelenmiş, hem bu alandaki literatürden hem de uygulamalardan yola çıkarak göstergeler çok yönlü analiz edilmiştir. Konuyla ilgili literatürün sınırlı olması, özellikle göstergeler özelinde kaynakların azlığı daha çok tecrübe ve uygulamalar üzerinden konuyu ele almamıza neden olmuştur.

Yerel yönetimlerde stratejik planlama ve performans yönetimi belirli bir mevzuata bağlı olarak şekillendiği için bu çalışmada önce mevzuat hakkında özet bilgilere yer verilmiş; ardından performans yönetimi sistematiği hakkında temel bilgilerden bahsedilmiş; daha sonra da performans göstergeleri hakkında detay analizlere geçilmiştir. Çalışma sonucunda da belirli çıkarımlar yapılarak sonuç bölümünde ifade edilmiştir.

\section{Performans Ölçümüne Dair Mevzuat}

Kamu alanında stratejik planlama ve performans yönetimine ilişkin mevzuatın ana çerçevesini 5393 Sayılı Belediye Kanunu ve 5018 Sayılı Kamu Mali Yönetimi ve Kontrol Kanunu oluşturmaktadır. Belediye Kanununun 41. Maddesi ile Kamu Mali Yönetimi ve Kontrol Kanunu'nun 9. Maddesi yerel yönetimlere doğrudan stratejik planlama sorumluluğu yüklemektedir. Ayrıca belediye başkanını da doğrudan sürecin sahibi olarak tanımlamaktadır. Belediye kanununda Belediye Başkanının Görevleri başlığı altında "Belediyeyi stratejik plâna uygun olarak yönetmek, belediye idaresinin kurumsal stratejilerini oluşturmak, bu stratejilere uygun olarak bütçeyi, belediye faaliyetlerinin ve personelinin performans ölçütlerini hazırlamak ve uygulamak, izlemek ve değerlendirmek, bunlarla ilgili raporları meclise sunmak." görevi ile planlama sürecinin hazırlanması, uygulanması ve sonuçlandırılması aşamalarıyla ilgili belediye başkanını belediye meclisine karşı sorumlu tutmaktadır.

Performans ölçümü, kurumun uzun vadeli amaç, hedef ve politikalarını ifade eden stratejik planla başlayarak performans programı, faaliyet raporu, belediye bütçesi, iç kontrol 
sistemi, iç denetim, Sayıştay denetimi gibi birçok alana uzanmaktadır. Dolayısıyla bu alandaki mevzuat da benzer şekilde genişlemektedir.

\section{Sayılı Belediye Kanunu;}

38. Maddesi (Belediye Başkanının Görevleri)

41. Maddesi (Stratejik Plan ve Performans Program1)

54. Maddesi (Belediyenin denetimi)

56. Maddesi (Faaliyet Raporları)

61. Maddesi (Belediye Bütçesi)

\section{Sayılı Kamu Mali Yönetimi ve Kontrol Kanunu;}

9. Maddesi (Stratejik Planlama ve Performans Esaslı Bütçe)

13. Maddesi (Bütçe İlkeleri)

41. Maddesi (Faaliyet Raporları)

64. Maddesi (İç Denetçinin görevleri)

\section{Yönetmelikler ve Rehberler;}

- Strateji Geliştirme Birimlerinin Çalışma Usul ve Esasları Hakkında Yönetmelik

- Kamu İdarelerinde Stratejik Planlamaya İlişkin Usul ve Esaslar Hakkında

- Kamu İdarelerince Hazırlanacak Performans Programları Hakkında Yönetmelik

- Performans Programı Hazırlama Rehberi

- Kamu İdareleri için Stratejik Planlama Kılavuzu

- Performans Denetim Rehberi 2014

- Kamu İç Kontrol Rehberi

- İç Kontrol ve Ön Mali Kontrole İlişkin Usul ve Esaslar

Temel kanunlar yanı sıra yönetmelik ve rehberler uygulamaya yönelik detayları ifade etmektedir. Yönetmelik ve rehberler incelendiğinde uygulama konusunda oldukça yeterli yönlendirme yapıldığı görülmektedir. Yönetmelikler bir hüküm ifade etmekle beraber rehberler kurumlar için faydalı yönlendirmeler yapma üzere tavsiye mahiyetindeki bilgilerden oluşmaktadır. 


\section{Yerel Yönetimlerde Performans Ölçümü}

Yerel yönetimlerde performans ölçümleri bir sistem yaklaşımıyla ele alınmaktadır. Kurumun vizyonuna bağlı olarak uzun vadeli amaç ve hedefler, buna bağlı olarak yıllık hedefler, hedeflere ulaşmak için gerekli faaliyetler, faaliyet maliyetleri, bütçe ve bu sürecin kontrolünü öngören tedbirlerden oluşmaktadır. Stratejik Plan (5 y1llık), Performans Programı (yıllık), Faaliyet raporu (yıllık), Performans Esaslı Bütçe (yıllık), İç Kontrol Sistemi (sürekli) olmak üzere kamu alanında yapılan performans değerlendirmelerinin temel dokümanlarıdır.

Yönetimin rasyonelleştirilmesi ve başarı ya da başarısızlığın belirli kriterlere bağlanması amacıyla ortaya çıkan bu uygulamalar daha kaliteli, etkin ve verimli hizmet üretimine aracılık etmesi ümit edilmektedir. Uzun vadeli amaç ve hedefler(stratejik plan), performans programı olarak bilinen yıllık

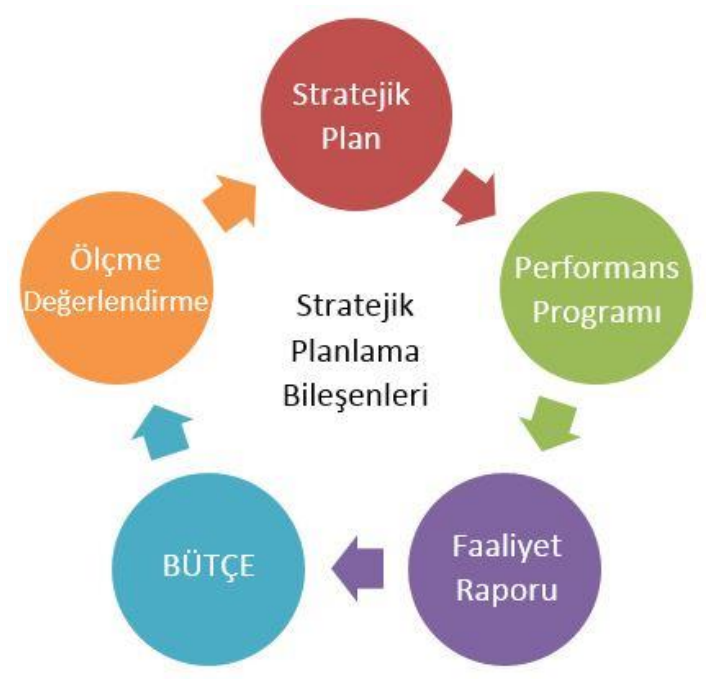
program aracılığıyla uygulamaya konmaktadır. Programda yer alan yıllık hedeflerin ölçülebilirliği ise "göstergeler" aracılığıyla sağlanmaktadır. Dolayısıyla hedeflerin isabetli oluşturulması kadar hedeflerin başarı kriterlerinin (göstergelerin) kapsamlı bir şekilde belirlenmesi önem arzetmektedir. Dahası performans ölçümünün ana omurgasını oluşturan hedeflere ait göstergelerin güvenilir verilerle yeterli ölçüm yapamadığı durumda tüm sistemin işe yaramaz hale geleceği görülecektir. Çünkü kamu alanında yönetimin etkinlik-verimlilik ve kalitesini algılamak ve artırmak için ölçmeye ihtiyaç duyulmaktadır. Ölçümün kalitesi büyük ölçüde gösterge kalitesine bağlıdır. Dolayısıyla "göstergeleri”" kendi başına ele almak yerine SP, PP, FR, PEB, İç kontrol sisteminden oluşan sistematik içerinde ele almak gerekir. Sistemin unsurları düzenli olarak birbirine veri aktarımında bulunarak bir döngü şeklinde çalışmaktadır. Bu döngünün en önemli unsuru ise göstergelerdir. Şimdi göstergelerin Performans Ölçümü sistematiğindeki yerini daha detaylı inceleyelim. 


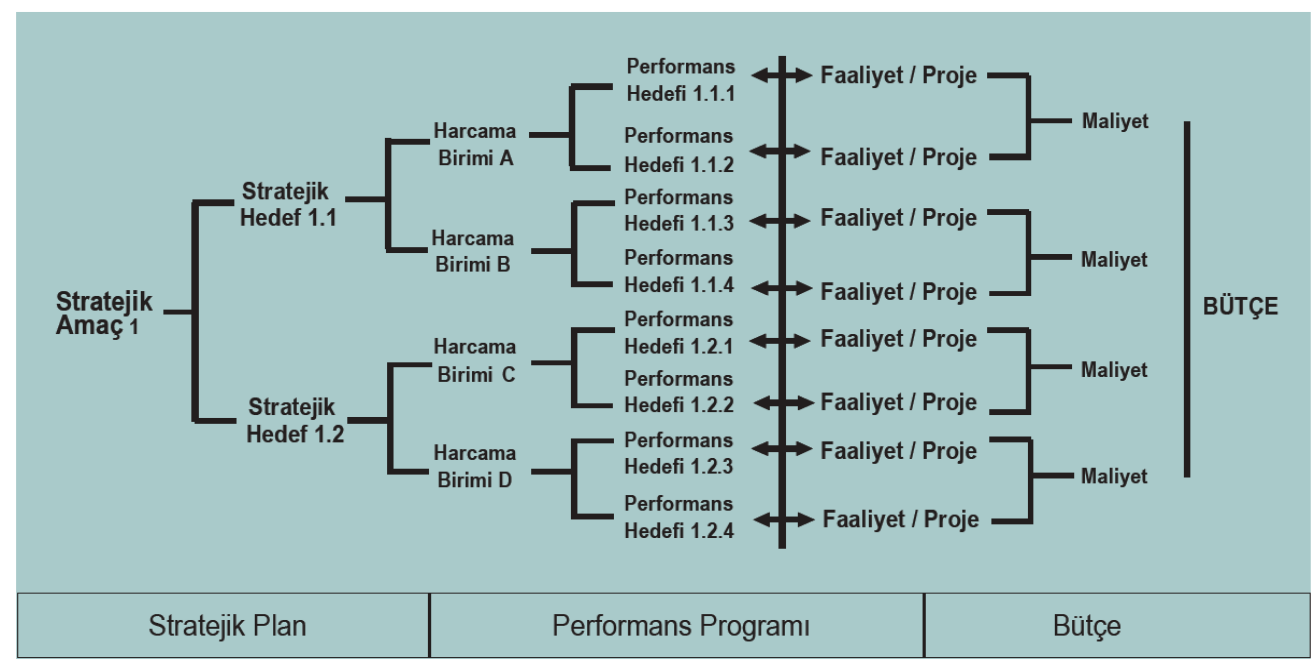

Şekil 1: Stratejik Plan, Performans Programı, Bütçe ilişkisi

\section{Yerel Yönetimlerde Performans Göstergeleri}

\subsection{Performans Göstergesi Nedir?}

Yerel yönetimlerde performans göstergelerinin ne olduğu ve nasıl oluşturulması gerektiğiyle ilgili mevzuatta temel bilgilere yer verilmiştir. Kamu idarelerinde stratejik planlamaya ilişkin 2006 yılında yayınlanan ve hala yürürlükte olan rehberde "Performans göstergeleri gerçekleşen sonuçların önceden belirlenen hedefe ne ölçüde ulaşıldığının ortaya konulmasında kullanılır. Bir performans göstergesi, ölçülebilirliğin sağlanması bakımından miktar, zaman, kalite veya maliyet cinsinden ifade edilir.” (DPT, 2006, s.36) şeklinde tanımlanmıştır.

Diğer taraftan Maliye Bakanlı tarafindan 2009 yılında yayınlanan "Performans Programı Hazırlama Rehberi” "nde ve Sayıştay Başkanlığı tarafından 2014 yılında yayınlanan “Performans Denetimi Rehberi”nde“Performans göstergesi, performans hedeflerine ulaşılıp ulaşılmadı̆̆ını ya da ne kadar ulaşıldığını ölçmek, izlemek ve değerlendirmek için kullanılan ve sayısal olarak ifade edilen araçlardır.”(Maliye Bakanlığı, 2009, s.6),(Sayıştay Başkanlığı, 2014, s.25) ifadesi ile özetlenmiştir.

Bu tanımlamalar gösteriyor ki göstergeler, kurumun hedefler aracılığıyla gelişiminde, ilerlemesinde, iyileşmesinde ne kadar yol aldığını kanıtlayan sayısal bilgilerden oluşmaktadır. Göstergeler tek yönlü olmayıp, hedefi çok yönlü yansıtması bakımından çeşitlilik göstermektedir. 


\subsection{Gösterge Türleri}

Girdi göstergeleri: Üretilen ürün ve hizmetlerin hangi kaynaklar kullanılarak üretildiğine ilişkin bilgi veren araçlardır.

Çıktı göstergeleri: Kurumun ürettiği nihai mal ve hizmet miktarına ilişkin bilgi sağlar. Çıktı göstergeleri belirlenirken ara çıktılar değil, sadece nihai çıktılar göz önüne alınır. Örneğin bir belediyeyi ele aldığımızda, yapılan yolların uzunluğu çıktı göstergesi olarak ele alınabilir.

Sonuç göstergeleri: Üretilen her türlü ürün veya hizmet bireyler ve toplum üzerinde birtakım etkiler meydana getirir. Bireylerin ve toplumun durumunda meydana gelen bu değişme sonuç göstergeleri aracılığıyla ölçülür. Örneğin Belediyeler tarafından işletilen meslek edindirme kurslarında "kurs sonrası işe girenlerin oranı" sonuç göstergesi olarak ele alınabilir. Sonuç göstergeleri uzun vadede elde edildiklerinden ve dişsal faktörlerden önemli ölçüde etkilendiklerinden ölçülmesi çıktı göstergeleri ile karşılaştırıldığında daha zordur. Ancak sonuç göstergeleri ile stratejik amaç ve hedefler arasında doğrudan ilgi kurmak mümkündür.

Verimlilik Göstergeleri: Belirlenen bir girdi düzeyi ile en yükssek çıktının elde edilip edilmediğine ilişkin bilgi sağlar. Verimlilikte artışın bir kurumda çıktı kalitesi düşürülerek arttırılması tehlikesi vardır. Örneğin girdi miktarı sabit iken daha fazla miktarda ancak daha düşük kalitede çıktı üretilmesi verimliliği arttırır. Bu nedenle verimlilik göstergelerinin kalite göstergeleri ile dengelenerek kullanılması gerekmektedir.

Etkililik Göstergeleri: Çıktıların beklenen sonuçlara yol açıp açmadığı etkililik göstergeleri ile ölçülür. Belirli bir çıktı toplumda istenen sonuçlara yol açacak şekilde kullanılıyorsa bu çıktıların etkili olarak kullanıldığı sonucuna varılır.

Kalite Göstergeleri: Kalite göstergeleri üretilen mal ve hizmetlerin hatasız, vaktinde, belirli standartlara uygun ve kullanıcıların isteklerini karşılayacak şekilde kullanılıp kullanılmadığını ölçer. Kalite göstergeleri ile bir hizmetin ne kadar iyi yerine getirildiği ölçülebilmesine karşın, bu hizmetlerin toplumda ne gibi sonuçlar meydana getirdiği ölçülememektedir. O yüzden kalite göstergelerinin tek başına kullanılmaması, sonuç göstergeleri ile dengelenmesi gerekir. 


\subsection{Göstergelerin özellikleri}

Kamu alanında performans ölçümünün en kritik unsuru olan göstergelerin belirli özellikleri taşıması gerekmektedir. Bu alanda oluşturulan mevzuat ve rehberler de bunu gerekli kılmaktadır. Performans ölçüm sürecinde göstergeler aracılığıyla kurumsal hedeflerin gidişatı hakkında somut bilgiler edinilebilmektedir. $\mathrm{Bu}$ göstergelerin makul ölçü ve standartlarda oluşturulması sürecin sağlıklı ilerlemesi bakımından önem arzetmektedir. Göstergelerin fonksiyonunu icra edebilmesi için asgari aşağıdaki şartları sağlaması gerekmektedir:(Performans Programı Hazırlama Rehberi, 2009, s.14)

\section{a) Performans hedeflerine ulaşılıp ulaşılmadığını ölçebilmelidir:}

Yerel yönetimlerde oluşturulan stratejik planlar ve performans programları incelendiğinde hedef ifadelerinin doğrudan sayısal olmadığı görülecektir. Hedefin sayısal bir karşılığının oluşturulması göstergeler üzerinden sağlanmaktadır. Hedefte ulaşılmak istenen nokta, buraya etkin ve verimli bir şekilde ulaşabilme, maliyet unsurları ve hedefe ulaşmak için yapılacak işlerin kalitesi "göstergeler” ile somutlaştırılmaktadır. Dolayısıyla göstergelerin performans hedeflerine ulaşılıp ulaşılmadığını ifade etmesi gerekir.

\section{b) Performans hedefini tüm yönleriyle ele almalıdır:}

Göstergelerin "kapsayıcı” olmasına özen gösterilmelidir. Yani göstergeler, hedefi tüm yönleriyle sorgulaması; girdi, çıktı, kalite, verimlilik, etkinlik, tutumluluk bakımından değerlendirmesi gerekir. Sadece çıktı odaklı göstergeler oluşturmak, hedefi tek boyutuyla değerlendirmek anlamına gelir ki, bu bize hedefi yetersiz ve yanlış değerlendirmemize yol açar. Dolayısıyla başarı ya da başarısızlığımız hakkında doğru verilere ulaşamayız.

\section{c) Ölçülebilir, ulaşılabilir, güvenilir veri sunacak nitelikte olmalıdır:}

Göstergelerin en temel özelliklerinden biri de ölçülebilir, ulaşılabilir ve güvenilir olmasıdır. Performans göstergelerinin, performans ölçümünün en kritik unsuru olduğunu ifade etmiştik. Performans ölçümünün sağlıklı sonuçlar vermesi büyük ölçüde göstergelerin kalitesine ve kapsayıcılığına bağlıdır. Göstergelerin sağlıklı sonuç vermesi ise "verilerin güvenirliği”ne bağlıdır. Dolayısıyla her şeyin temelinde güvenilir veri yatmaktadır. Çünkü 
ölçüm sürecinin hammaddesidir güvenilir veri. Bu veriler göstergelere dönüşerek işlenmeye başlanmakta ve performans ölçüm sürecine girmektedir. Verinin güvenirliği kadar ölçülebilir olması, ölçülebilir nitelikte kayıtların tutulması gerekmektedir. Sağlam veri kaynakları, göstergelerin daha kaliteli oluşturulmasına yardımcı olacaktır. Ulaşılmak istenen hedefin göstergeler aracılığıyla iyi bir şekilde ifade edilebilmesi göstergenin ölçülebilir nitelikte ve güvenilir sonuçlar üretmesine bağlıdır. Dolayısıyla güvenilir veri sunmayan göstergeler performans ölçüm sürecine katılmamalıdır. Örneğin "inşaat ruhsatı verme süresi” bir gösterge olarak konulmuşsa ve bu işin tüm aşamaları süre bazında ölçülemiyorsa, gösterge oluşturmak yerine inşaat ruhsatı verme sürecinin kontrol altına alınmasına, aşamalarının belirlenmesine ve sürelerin tayin edilmesine odaklanılmalıdır.

Hastürk'ün ilgili makalesinde vurguladığı gibi Performans göstergelerinin oluşturulması ve değerlendirilebilmesi, ancak uygun veri ve istatistiklerin temin edilmesi ile mümkündür. Amaca uygun, doğru ve tutarlı verilerin varlığı, performans göstergelerinin oluşturulması, performansın ölçülmesi ve değerlendirilmesi için olmazsa olmaz bir ön koşuldur. Ne tür verilere ihtiyaç duyulduğu, bunların ne şekilde temin edileceği, ihtiyaç duyulan veriler halihazırda toplanmıyorsa nasıl ve ne sıklıkla kim tarafindan temin edileceği, bu kapsamdaki kısıtların neler olacağı gibi hususların mutlaka incelenmesi ve cevaplanması gerekir. (Hastürk, 2006, s85)

\section{d) Hem geçmiş dönemlerin hem de diğer idarelerin benzer göstergeleriyle karşılaştırılabilir olmalıdır,}

Yerel yönetimlerin görev alanının çerçevesi kanunla belirlendiğinden yerel yönetimlerde her yıl büyük oranda benzer faaliyetleri icra edilmektedir. Hatta hedefler de geçmiş yıllara göre fazlaca benzeşmektedir. Dolayısıyla her yıl benzer faaliyetleri yapan belediyelerde geçmiş yıllarla mukayese gidişatı algılama bakımından kolaylık sağlamaktadır. Diğer taraftan benzer şekilde faaliyet gösteren Türkiye genelinde bine yakın belediye ile özellikle benzer özellikler taşıyan belediyelerle mukayese yapmak bir belediye için önemli bir katkı olacaktır. Dolayısıyla göstergelerin hem yıllar itibariyle hem de diğer benzer kurumlarla kıyaslama yapmak imkanı sağlaması performans ölçümü sürecinde önem arzetmektedir. Bu durum "performans değerlendirmesi”" aşamasına da işlevsel bir veri sağlamaktadır.

e) Verilerinin elde edilme ve değerlendirme maliyetleri makul ve kabul edilebilir bir 
seviyede olmalıdır.

Yerel yönetimler kar amacı gütmeyen kurumlar olmasına rağmen her bir faaliyet için karlılık, tutumluluk ilkelerini gözetmek zorundadır. Bir verinin elde edilme maliyeti o veri üzerinden üretilen değerden daha pahalı olmamalıdır. Bu genel prensipten yola çıkarak göstergelerin oluşturulması için ihtiyaç duyulan verilerin maliyetleri makul olmalıdır. Elde edilecek verinin kritikliği ve diğer faaliyetler üzerindeki belirleyici etkisi o veriyi elde etmemiz için daha yüksek maliyetleri gerekli kılabilir. Ancak öncelik ve önem derecesi orta veya düşük olan verilerin elde edilmesi için gereksiz maliyetlerden kaçınmak gerekir. Yerel yönetimlerde çoğu zaman "personel” bir maliyet unsuru olarak algılanmadığından verilerin elde edilmesinde fazla personel istihdam edilmesi riskini dikkate almak gerekir.

\subsection{Performans ölçümü ve göstergeler}

Mahalli idarelerde performans ölçümü ve değerlendirmesi için kullanılan en önemli araç performans göstergeleridir. (Nangır, 2007, s.120)Performans ölçümünde göstergelerin rolü, "belirlenen hedeflere ne düzeyde ulaşıldığının sayısal olarak ölçülebilirliğinin sağlanması" olarak ifade edilebilir. Performans ölçümünün temelinde "ölçme” vardır. Kamu mevzuatına göre de ölçmenin ancak göstergeler aracılığıyla yapılabileceği belirtilmiştir. Yerel yönetimler yıllık performans programını oluştururken her bir hedef için çeşitli göstergeler atamaktadır. $\mathrm{Bu}$ göstergelere göre hedeften beklentiler ortaya konulmakta ve sonuçlar değerlendirilmektedir. Dolayısıyla hedef-gösterge ilişkisi performans ölçüm sistematiğinde önemli hale gelmektedir. Diğer kamu kurumlarında olduğu gibi yerel yönetimlerde de performans hedefleri göstergelerle ilişkili olarak "Performans Programı Rehberi"nde belirtilen tablo esas alınarak hazırlanmaktadır. Bu tablo kurumlar için sadece bir örnek niteliğindedir. Ancak yerel yönetimlerin ve diğer kamu kurumlarının birçoğu tabloyu aynen kullanmayı tercih etmiştir. 
Tablo 1: Performans Programı Rehberine Göre Performans Hedefi Tablosu

İdare Adı

\begin{tabular}{|l|l|}
\hline Amaç & \\
\hline Hedef & \\
\hline
\end{tabular}

\begin{tabular}{|l|l|}
\hline Performans Hedefi 1 & \\
\hline Açıklama : & \\
\hline
\end{tabular}

\begin{tabular}{|c|c|c|c|c|}
\hline \multicolumn{2}{|r|}{ PERFORMANS GÖSTERGELERİ } & $(\mathrm{t}-1)$ & (t) & $(\mathbf{t}+\mathbf{1})$ \\
\hline 1 & & & & \\
\hline 2 & & & & \\
\hline 3 & & & & \\
\hline 4 & & & & \\
\hline 5 & & & & \\
\hline 6 & & & & \\
\hline
\end{tabular}

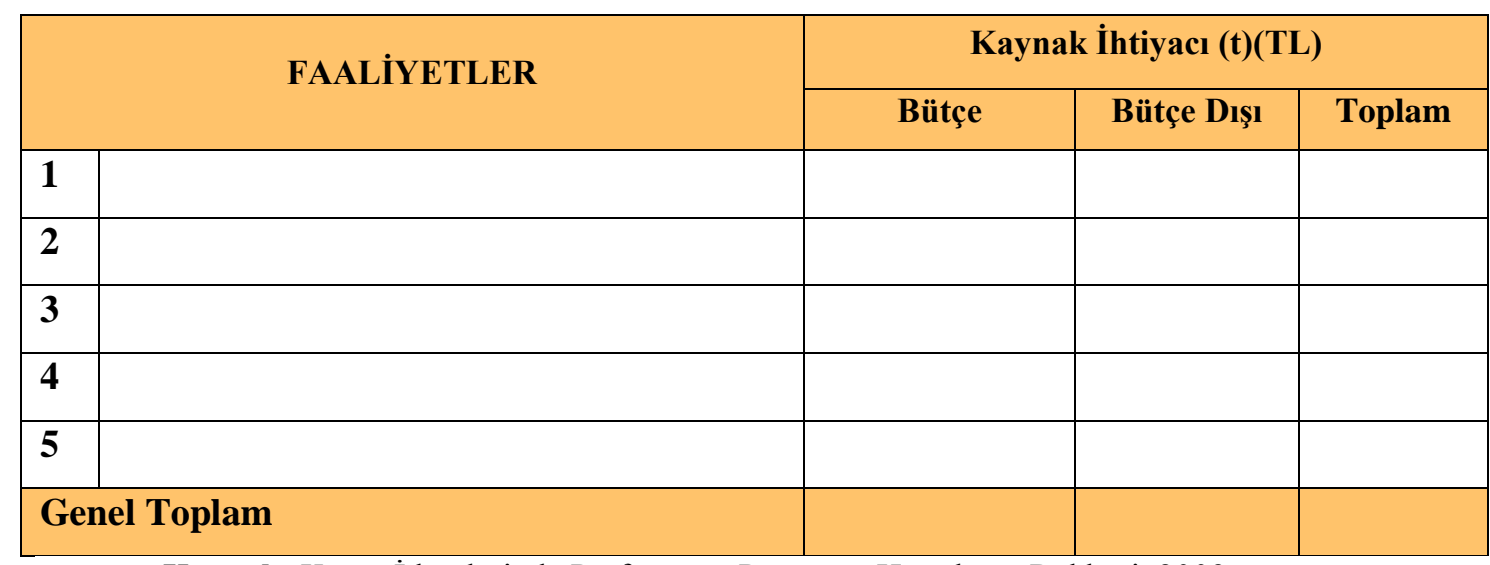

Kaynak: Kamu İdarelerinde Performans Programı Hazırlama Rehberi, 2009

Tabloya göre önce stratejik amaç ve hedefler, sonra y1llık performans hedefleri oluşturulmaktadır. Hedef ifadesi genellikle sayısal ifade edilmeyip, sayısal ifadelere göstergeler kısmında yer verilmektedir. Hedeflerin neden sayısal olarak belirtilmediği çoğu zaman eleştirilmiştir. Hedefler sayısal olarak ifade edilmiş olsaydı hedef sadece çıktı olarak “x işinden n tane yapmak" şeklinde tek boyutlu ele alınacaktı. Oysa göstergelerle, bir hedeften onlarca beklentimizi görebilir ve analiz edebiliriz. Bu yüzden göstergeler girdi, çıktı, sonuç, kalite, verimlilik, tutumluluk, etkinlik olarak çeşitlilik göstermektedir. 
Performans ölçüm sürecinde göstergeler oluşturulurken birçok faktör dikkate alınmaktadır. Göstergeleri etkileyen faktörleri şu şekilde ifade edilebilir.

- Faaliyetlerin niteliği

- Faaliyetin doyum noktasına ulaşıp ulaşmadığı (Mevcut Durum Raporları)

- Mali kisitlilık

- Verilerin güvenirliği

Kurumun faaliyetleri ve bu "faaliyetlerin niteliği" gösterge oluşturma sürecini etkileyen önemli başlıklardan biridir. Bu kapsamda faaliyetleri iki kısımda ele alabiliriz.

a) Bir müracaatla başlatılan, çıktıların niceliğ̈inin önemli olmadı̆̆ faaliyetler:

$\mathrm{Bu}$ tür faaliyetler inşaat ruhsatı, iskan belgesi verilmesi, yıkım ruhsatı, işyeri ruhsatları, asansör ruhsatı, yapı denetim, tevhit-ifraz işlemleri, kat irtifakı kurulması, tapu tahsisleri, toplum düzeniyle(zabıta) ilgili gelen talepler, emlak beyan1, vergi ödemeleri, evlilik ve nikah işlemleri, BİMER, Bilgi edinme müracaatları, vatandaş ve kurumlar tarafından yapılan araç(otobüs) talepleri gibi bir yılda ortaya çıkacak iş yükünün öngörülmesinin zor olduğu faaliyetlerdir. $\mathrm{Bu}$ tür faaliyetler müracaatla gerçekleştiği için "bir yılda n tane yapmak" şeklinde bir çıktı göstergesi oluşturmak zor gibi gözüküyor. Böyle durumlarda çıktı göstergelerinden çok işin müracaat edenin beklentilerine ve memnuniyetine uygun bir şekilde sonuçlanması için kalite göstergeleri (işin süresi, memnuniyet vb.) ön plana çıkarılabilir. Bu faaliyetlerde çıtının az ya da çok olmasının bir önemi yoktur. Temel amaç müracaatın karşılanmasıdır. Bazı kurumlarda bu tür faaliyetlere ilişkin göstergeler "İzleme Göstergesi” olarak takip edilmektedir. Ümraniye Belediyesi gibi bazı kurumlarda ise her faaliyetin bir maliyet unsuru olduğu görüşünü benimseyerek (geçmiş yılların gerçekleşme düzeyini baz alıp) bu tür faaliyetlerin çıktılarını da performans göstergesi olarak ifade etmişlerdir. (2015 y11 Performans Programı, Ümraniye Belediyesi)

b) Kurumun inisiyatifiyle başlatılan, çıktıların niceliğinin önemli olduğu faaliyetler:

$\mathrm{Bu}$ tür faaliyetler altyapı çalışmaları, çevre temizlik, geri dönüşüm, park ve yeşil 
alan yapımı, kültürel etkinlikler, spor hizmetleri gibi kurum inisiyatifiyle başlatılan (doyum noktasına ulaşmamışsa) mümkün olduğunca daha fazla yapılması arzu edilen faaliyetlerdir. Burada çıktılar önemli hale gelmektedir. Bu tür faaliyetlerle ilgili gösterge oluştururken A noktasından B noktasına gidişat daha net görülebilmektedir. Dolayısıyla göstergeler oluşturmanın da daha kolay olduğu faaliyetlerdir. Ancak göstergeleri sadece çıktı odaklı değil, özellikle kalite ve verimlilik sorgulamayası için veri oluşturabilecek şekilde planlamak gerekir.

Faaliyetlerin doyum noktasına göre durumu göstergeleri etkilen önemli unsurlardan biridir. Yerel yönetimler hedeflerini belirlerken "hep daha fazlası" düşüncesiyle hareket etme eğilimindedirler. Burada ihtiyaç düzeyinin net bir şekilde ortaya konması ve buna göre gösterge değerlerinin oluşturulması oldukça önemlidir. Kurumların düzenli mevcut durum raporları üreterek her bir faaliyetle ilgili envanter oluşturmaları o faaliyetlerle ilgili ihtiyaç düzeyinin tespiti noktasında yardımcı olacaktır. Mevcut durumun doğru şekilde bilinemediği durumlarda göstergeler olumsuz sonuçlar da doğurabilir. Örneğin bir hedef kapsamında yağmursuyu kanalı yapmayı planlayan bir kurum mevcut yağmursuyu ağını bilmek zorundadır. Öncelik ve aciliyet prensibine göre o yıl için hangi sokaklara yağmursuyu kanalı yapılacağı tespit edilmeli, buna göre veriler göstergelere yansıtılmalıdır. Dolayısıyla işin \%100’ü hakkında bilgi sahibi olmadan bir kısmı hakkında net göstergeler ortaya koymak zor olacaktır.

Faaliyetlerin doyum noktasına ulaşıp ulaşmadığının sorgulanması geçmiş yıllarla mukayese yaparken de yardımcı olmaktadır. Yerel yönetimlerin göstergeleri incelendiğinde kurumun başarısı "bir önceki yıla göre daha fazla çıktı üretmesine bağlı olduğu kanaati ön plana çıkmaktadır. Halbuki "ihtiyaç düzeyinin” baz alınması gösterge oluşturmada temel prensiptir. İhtiyaç düzeyi her faaliyet için yıldan yıla farklılık göstermektedir. Bazı yıllarda azalabilir bazı yıllarda artabilir. Dolayısıyla geçen yıl 15 adet park yapılmışken, bu yıl 3 adet park yapılması peşinen negatif bir algı oluşturmamalıdır. Burada "Performans Değerlendirmesi” önemli hale gelmektedir. Performans değerlendirmesinde bu faaliyet geçen yıla göre azalmış gözükse de ihtiyaçlar bunu gerekli kılmış olabilir. Dolayısıyla bu haliyle son derece başarılı bir sonuç olarak kayda geçebilir.

Gösterge oluştururken temel belirleyici faktörlerden bir diğeri mali kısıtlılıktır. Aslında mali kısıtlılıktan etkilenen hedeflerdir. Hedeflerin sayısal karşılıkları göstergeler üzerinden ifade edildiğinden göstergelerin mali boyutu önemli hale gelmektedir. Bir gösterge oluşturulurken (özellikle çıktı göstergelerinde) bütçe bakımından kurumun tolere edebileceği 
sınırlarda olup olmadığı dikkate alınmalıdır. Dolayısıyla göstergeler bütçenin şekillenmesinde bir etken iken göstergelerin şekillenmesinde de bütçe bir etken olarak karşımıza çıkmaktadır. İhtiyaç düzeyinin yüksek olduğu faaliyetlerde ancak mali sınırlar çerçevesinde faaliyet üretilebilir. Dolayısıyla özellikle çıktı ve sonuç göstergeleri buna göre atanmalıdır. Bu yıl 4 kültür merkezi yapan bir belediye, bir sonraki yıl mali sebeplerden dolayı 1 kültür merkezi yapmayı planlamış olabilir. Bunlar kurum için doğrudan başarı ya da başarısızlık gerekçeleri değildir. Kapsamlı bir performans değerlendirmesi yaptıktan sonra başarı ya da başarısızlık konusunda söz söylenebilir.

Performans ölçüm sürecinde "verilerin güvenirliği”" de göstergelerin etkilendiği belirleyen faktörlerdendir. Hatta verilerin güvenirliği konusu stratejik planlama ve performans yönetimi sürecinin en temel altlığını oluşturmaktadır. Sürecin yönlendirilmesinde önemli bir role sahiptir. Hedefleriniz ne kadar güçlü ve iddialı olursa olsun yanlış veriler kurumu arzu etmeyeceği sonuçlara götürebilir. Sayıştay denetiminin de bir konusu olan verilerin güvenirliği tüm faaliyetleri ve tüm personeli ilgilendirmektedir. Dolayısıyla kurum olarak üst yönetimden en alt çalışana kadar topyekûn bir duyarlılık geliştirmek gerekir. Gösterge oluşturulurken yararlanılan verilerin kaynağının sorgulanması performans ölçüm sürecinin sağlıklı yürümesi için gerekli bir adımdır. Yerel yönetimlerde personel değişimlerinin fazla olduğu birimlerde veri güvenliğini sağlayacak tedbirler almak gerekir. Bu İç Kontrol Sisteminin de bir parçasıdır. (Kamu İç Kontrol Rehberi, Maliye Bakanlığı.)

\subsection{Performans Değerlendirmesi ve Göstergeler}

Kamu alanında stratejik planlama ve performans ölçümüne ilişkin mevzuatın yürürlüğe girmesiyle birlikte geleneksel denetimler yanı sıra "Performans Değerlendirmesi" adıyla yeni bir denetim modeli uygulamaya konulmuştur. Geleneksel denetim, kurumların önceden belirlenen kanunlara ve diğer hukuki düzenlemelere uygun hareket edip etmediğini tespit ederken "performans değerlendirmesi” kurumun yaptığı faaliyetlerin amaç ve hedeflere ne kadar hizmet ettiği ile kamu hizmetlerinin etkili ve verimli bir şekilde yerine getirip getirmediğini saptamaktadır.(Yenice, 2006, s.124)Dolayısıyla stratejik planlama ve performans ölçüm sürecinin gerçek anlamda kuruma katkısı kapsamlı bir "performans değerlendirmesi” sonrasında anlaşılabilir. Performans değerlendirmesi yaparken en önemli verilerden biri performans göstergeleridir. Performans değerlendirmesinin sağlıklı sonuçlar üretmesinde göstergelerin hedefi tüm yönleriyle el alıyor olmasının ve gösterge değerlerinin son derece güvenilir olmasının payı büyüktür. Sınırlı ve sıradan göstergelerle yapılacak 
değerlendirmeler kurum yöneticilerinin karar alma sürecini olumsuz yönde etkileyecektir. Dolayısıyla gösterge kalitesi "performans değerlendirme" aşamasının da belirleyici unsurlarından biridir.

\subsection{Sayıştay Denetimi ve Göstergeler}

Yerel yönetimler Sayıştay denetimine tabi kurumlardır. 6085 sayılı Kanunun 36. maddesine göre Sayıştay’ın denetim görevleri, “düzenlilik denetimi” ve "performans denetimini” kapsamaktadır. 6085 sayılı Kanunun 36. maddesinde performans denetimi aşağıdaki gibi ifade edilmiştir: "Hesap verme sorumluluğu çerçevesinde idarelerce belirlenen hedef ve göstergelerle ilgili olarak faaliyet sonuçlarının ölçülmesi suretiyle gerçekleştirilir." (Sayıştay Kanunu, 36.madde)

Yeni Sayıştay denetimi modelinde cari yıla ilişkin evrak ve dokümanlar incelenmekte; ayrıca kurumun amaçları, hedefleri, politikaları ile bunlara ulaşmak için oluşturulan performans ölçüm sistemleri değerlendirilmektedir.

Sayıştay denetiminin "Performans denetimi”" olarak adlandırılan bölümüyle ilgili 2014 yılında yeni bir rehber (Performans Denetim Rehberi) yayınlanmıştır. Yayınlanan "Performans Denetim Rehberi” yerel yönetimleri de kapsayacak şekilde kamu alanında Sayıştay müfettişleri tarafından yapılacak performans denetiminin çerçevesini oluşturmaktadır. Rehberde "Yönetsel sorumluluk bağlamında idarelerin hazırladı̆̆ı plan ve programların (amaç ve hedefler, faaliyetler ve performans hedefleri bağlamında) değerlendirilmesi görevi performans denetimi yetkisi ile Sayıştay'a verilmiştir."......." Kurumsal düzeyde performans denetimi, idarenin plan ve program belgelerinin ışığında izleyeceği yolu ortaya koyan amaç ve hedefleri ile bütçe uygulaması sonucunda ortaya çıkan faaliyet sonuçlarının performans göstergeleri çerçevesinde ölçülmesi şeklinde yapılır."

Buradan da anlaşılacağı üzere Sayıştay’ın yapmış olduğu performans denetiminin ana unsurlarından biri performans göstergeleridir. Performans ölçümünde hedeflere ne düzeyde ulaşılıp ulaşılamadığı göstergeler üzerinden sağlandığından göstergeler Sayıştay denetiminin ilgi odağında yer almaktadır.

Rehberin "Performans Programının Değerlendirilmesi" bölümünde göstergelerin ilgililiği (performans hedeflerine ulaşılıp ulaşılmadığını ya da ne düzeyde ulaşıldığının ölçülebilmesi, izlenebilmesi ve değerlendirilebilmesi bakımından performans hedefleri ile 
doğrudan ilgisi) sorgulanmaktadır. Ayrıca “Göstergenin performans hedefiyle ilgisinin kurulamadığı hallerde göstergenin ilgili olmadığı bulgusuna raporda yer verilir." ifadesine yer verilmiştir.

Rehberde "ölçülebilirlik” kriterlerine ilişkin bilgilerin yer aldığ 1 bölümde performans hedefi ve göstergelerinin ölçülebilirlik kriteri temelinde değerlendirilmesine ilişkin tablo aşağıda yer almaktadır.

Tablo 2:Ölçülebilirlik Kriteri Değerlendirmesi Tablosu

\begin{tabular}{|l|l|l|}
\hline \multicolumn{1}{|c|}{ Performans Hedefi } & \multicolumn{1}{|c|}{ Performans Göstergesi } & \multicolumn{1}{c|}{$\begin{array}{c}\text { Ölçülebilirlik } \\
\text { Değerlendirmesi }\end{array}$} \\
\hline $\begin{array}{l}\text { Spor tesis hizmetlerine } \\
\text { erişebilirliği \%10 arttırmak. }\end{array}$ & $\begin{array}{l}\text { Katılımcıların spor tesislerinden } \\
\text { faydalandığı ücretsiz seans sayısında } \\
\text { bir önceki yıla göre artış oranı (\%...) }\end{array}$ & Ölçülebilir \\
\hline $\begin{array}{l}\text { Sigorta prim gelirlerinin ve } \\
\text { primlere ilişkin tüm } \\
\text { alacaklarının tahsilatının } \\
\text { arttırılması }\end{array}$ & $\begin{array}{l}\text { İcra tahsilat tutarının bir önceki yıla } \\
\text { göre artış oranı (\%...) }\end{array}$ & Ölçülebilir \\
\hline $\begin{array}{l}\text { Otoyollarda kar ve buzla } \\
\text { mücadeleyi etkinleştirmek }\end{array}$ & $\begin{array}{l}\text { Otoyol ağımızda kar ve buzlanmanın } \\
\text { üstesinden gelinmesi konusunda } \\
\text { başarı elde edilecektir. }\end{array}$ & $\begin{array}{l}\text { Ölçülebilir değildir. } \\
\text { Başarının ölçütü } \\
\text { belirlenmemiştir. }\end{array}$ \\
\hline $\begin{array}{l}\text { Kurum taşınmazlarından elde } \\
\text { edilen kira gelirlerinin tahsilat } \\
\text { oranının artırılması }\end{array}$ & $\begin{array}{l}\text { Kiralama işleminde görev alan } \\
\text { personel sayısının yeterli olması }\end{array}$ & $\begin{array}{l}\text { Ölçülebilir değildir. Kişi } \\
\text { sayısının yeterli olması } \\
\text { hususu subjektiftir. }\end{array}$ \\
\hline
\end{tabular}

Kaynak: Performans Denetimi Rehberi, Sayıştay Başkanlığı, 2014.

Sayıştay denetiminde performans yönetiminin objektif ölçülebilir kriterlere bağlı olarak gerçekleşip gerçekleşmediği sorgulanırken özellikle göstergelerin ölçülebilirliği ve kapsayıcılığı üzerinde durulmaktadır.

\section{Sonuç Ve Öneriler}

Yerel yönetimlerde Stratejik Plan, Performans Programı, Faaliyet Raporları, İç Kontrol Sistemi gibi yönetsel çalışmaların merkezinde "ölçme” vardır. Çünkü ölçemediğiniz şeyi yönetemezsiniz. Ölçüm için de doğru ve yeterli "göstergelere" ihtiyaç vardır. Hem uzun 
vadeli amaç ve hedefler; hem de yıllık hedeflerin başarısının merkezinde "göstergeler" yer almaktadır. Hedeflerin ve faaliyetlerin maliyet/bütçe boyutu da yine göstergelere bağlı olarak şekillenmektedir. Dolayısıyla göstergelerin kalitesi, hedeflerin ve topyekûn stratejik planlama ve performans ölçüm sürecinin kalitesini büyük ölçüde etkilemektedir.

Performans yönetimine ilişkin rehberlerde göstergeler “....performans hedeflerine ulaşılıp ulaşılmadığını ya da ne kadar ulaşıldığını ölçmek, izlemek ve değerlendirmek için kullanılan ve sayısal olarak ifade edilen araçlar" olarak tanımlanmaktadır. Dolayısıyla amaç ve hedeflere ne düzeyde ulaşıldığı göstergeler üzerinden ölçülürken, bu sürecin etkili bir şekilde yönetilmesi büyük ölçüde göstergelerin özelliklerine, gösterge kalitesine ve göstergeyi oluşturan verilerin güvenirliğine bağlı olacaktır. Amaçları, hedefleri ve politikaları uygun olan bir kurumda göstergelerin yetersiz ve kalitesiz olması performans ölçüm sistematiğini topyekûn olumsuz etkileyecektir. Dolayısıyla performans yönetimin temel amacı olan "kurumsal ilerlemenin kontrollü bir şekilde ölçülüp izlenmesi" konusunda net sonuçlar ortaya koyamayı.

$\mathrm{Bu}$ bakımdan yerel yönetimlerde "göstergeler" stratejik planlama ve performans yönetiminin merkezinde yer alan belirleyici bir faktördür. Göstergeler, göreceli ve yorumsal hedefleri daha rasyonel ve ölçülebilir alana çekmektedir.

Diğer taraftan göstergeler hedefleri çok yönlü ölçen araçlardır. Bu yönüyle oldukça önemli katkı sağlamaktadır. Geleneksel ölçüm yöntemlerinde sadece çıktıların ifade edildiği tek boyutlu hedefler yer alıyordu. Yeni performans ölçüm modelinde bir hedeften beklenen çıktı, sonuç, girdilerin durumu, verimlilik, etkililik, ekonomiklik gibi unsurlarla hedef tüm yönleriyle ele alınmaktadır. Bir işi daha fazla yapmanın yanı sıra işin süresi, hızı, kalitesi, müşteri memnuniyeti, işin sonuçlarının müşteri üzerindeki kısa ve uzun vadedeki etkisi, işin maliyet boyutu gibi hususlar önemli hale gelmiştir.

Dolayısıyla performans ölçüm ve değerlendirme sürecinde;

- Göstergelerin sürecin başarısı için en temel unsurlardan biri olduğu her zaman dikkate alınmalıdır.

- Göstergelerin oluşumunda kullanılan verilerin doğru ve güvenilir veri olduğundan emin olunmalıdır. Güvenilir verinin olmadığı yerlerde önce verilerin doğru bir şekilde temin edilmesi, muhafazası ve veri üreten personelin eğitimi gibi konularda çalışma yapılmalidir. 
- Bir hedefi ifade eden göstergelerin, hedefi tüm yönleriyle yansıttığından emin olunmalidir.

- Gösterge oluştururken alışılagelmiş bir şekilde bir önceki yıla göre tahmin yürütmek yerine; kurumun ihtiyaç düzeyi, iş yapma kapasitesi, üst yönetimin beklentisi gibi konularda ciddiyetle değerlendirmeler yapılmalıdır.

- Göstergelerin gerçekleşme düzeyleri incelenirken geçmiş yılların gerçekleşme düzeylerinin üzerine çıkmayı temel gaye edinilmemelidir. İhtiyaç düzeyi ve işin doyum noktası o göstergenin optimal değeri hakkında daha doğru fikir verecektir.

- Yerel yönetimlerin tabi olduğu İç Kontrol Standartları'nın “Görevler Ayrılı̆̆ı” maddesi uyarınca bir görevli hem karar verici, hem uygulayıcı hem de denetleyici olamaz.(Kamu İç Kontrol Standartları Tebliği, 2007, Madde 9.1)Dolayısıyla kritik öneme sahip göstergeler ve göstergelere ait sayısal veriler uygulayıcı olan müdürler tarafından değil, karar merci olan üst yönetim tarafından konulmalıdır. Birim müdürleri üst yönetimin ihtiyaç duyduğu bilgileri sağlama konusunda yardımcı olmalıdırlar.

- Göstergelerin gerçekleşme yüzdeleri, ilgili kişileri yargılamak için bir araç olarak görülmemelidir. Her bir olumsuzluk iyileştirme firsatları içermektedir. İyileştirme odaklı olunmalı, kişisel yargılardan uzak durulmalıdır.

- Performans hedeflerinin gerçekleşme düzeyleri doğrudan bir kurumun başarı ya da başarısızlığı hakkında fikir vermeyeceği bilinmelidir. Ancak kapsamlı bir "performans değerlendirmesi” ile o hedefin, göstergenin ya da topyekün kurumun başarı/başarızlığı hakkında görüş beyan edebiliriz. Dolayısıyla performans programının, özelde de göstergelerin kurumsal gelişimi anlama ve yönlendirme konusunda sadece bir unsur olduğu kabul edilmelidir.

- Hedeflerin maliyetleri ve birim bütçeleri oluşturulurken temel referans noktasının yine göstergeler olduğu dikkate alınmalıdır.

- Faaliyetlerin niteliği göstergeler üzerinde belirleyici olmaktadır. Müracaatla başlatılan rutin faaliyetlerde (örneğin yapı ruhsatı, nikah sarayı faaliyetleri vb.) kalite odaklı göstergelere ağırlık verilmelidir. Kurum insiyatifi ile başlatılan özellikle yatırımsal faaliyetler için çok yönlü göstergelerle işin hem çıktısı, hem kalitesi hem de verimliliği sorgulanmalidir. 
- "Vatandaş memnuniyeti" bir sonuç göstergesi olduğundan hedef ifadelerinde vatandaş memnuniyetine yer verilmemelidir. Faaliyetlerin vatandaş üzerindeki etkisi ve vatandaş memnuniyetleri göstergeler aracılı̆̆ıyla izlenmelidir.

Benzer şekilde birçok öneri oluşturulabilir. Ancak genel çerçeve aynı olmak şartıyla her kurum kendine özgü yöntemlerle kurumsal iyileşme ve ilerlemeyi nasıl sağlayacağının yolunu bulmalıdır. Sonuç olarak yerel yönetimlerin yıllar itibariyle kurumsal planlama alanında tecrübe kazandığı, görece ilerleme kaydettiği söylenebilir. 2006'dan 2015 yılına kadar geçen sürede iki ya da üç stratejik plan dönemi; dokuz performans programı dönemi geçiren belediyelerin tüm yönetim sistematiğini mevzuatta oldukça detaylı tanımlanan stratejik planlama üzerine kurguladığı, yönetim kararlarını buradan elde edilen veriler üzerinden oluşturduğu düşünülebilir. Henüz bu aşamaya gelindiğine dair ipuçları bulmak zor. Burada performans yönetiminin başarısını etkileyen elbette birçok faktör vardır. $\mathrm{Bu}$ faktörlerden en önemlisi gösterge mantığının yerleşmemiş olmasıdır. Göstergelerin kaliteli ve kapsayıcı olmadığı durumlarda ideal hedefler de ölçülebilir olmaktan uzaklaşmakta, hatta üst yönetim kararlarını manipüle edecek konuma gelmektedir. 


\section{Kaynakça:}

- Devlet Planlama Teşkilatı, "Kamu İdareleri için Stratejik Planlama Kılavuzu”, 2006.

- Hastürk, Mesut. "Stratejik Planlama ve Performans Esaslı Bütçeleme”, Güncel Mali Sorunlar, Muhasebat Kontrolörleri Derneği, Sayı: 11, 2006.

- Maliye Bakanlığı, Kamu İç Kontrol Standartları Tebliği, 2007

- Maliye Bakanlığı, "Performans Programı Hazırlama Rehberi”, 2009.

- Maliye Bakanlığı, Kamu İç Kontrol Rehberi.

- Nangır, Esin. "Mahalli İdarelerde Performans Ölçümü”, Bütçe Dünyası Dergisi, Cilt 2, Sayı:25, Bahar 2007.

- Sayıştay Başkanlığı, "Performans Denetimi Rehberi”,2014.

- 6085 sayılı Sayıştay Kanunu, 2010.

- Ümraniye Belediyesi, 2015 yılı Performans Programı, İstanbul, 2015.

- Yenice, Ebru. “Performans Değerlendirmesi”, Maliye Dergisi, Say1:150, 2006. 